POLISH POLITICAL SCIENCE

VOL XLI 2012

PL ISSN 0208-7375

\title{
THE VECTORS OF POLISH MIGRATION IN THE WORLD
}

\author{
by Andrzej Chodubski
}

The migrations of population are considered to be one of fundamental values in the life of cultures and civilisations ${ }^{1}$. They are regarded as a force that generates social and economic progress, political aspirations, a "school" of attitudes, behaviour, tolerance, entrepreneurship, criticism. At the same time it is pointed out that they should not be a spontaneous phenomena and process. It is essential to prepare oneself for functioning in an immigration reality, for various barriers reveal themselves in it and are overcome by immigrants only with effort. The psychological factor is important in this respect. A number of people encounter difficulties to adapt to a new cultural reality because of their personality (e.g. because of neuroticism, distrust towards the outside world, introvertism).

In a situation in which immigration is accepted as an important freedom right of each individual and a high level of spatial mobility of people is observed, the following challenges are considered substantial from the perspective of its development in civilisation:

\footnotetext{
${ }^{1}$ Ref. A. Chodubski, Współczesna tożsamość diaspory polskiej w przemówieniach Jana Pawła II, “Rocznik Polonii” 2006, Vol. 2, pp. 96-109.
} 
1. Introduction of international norms and standards in immigration order,

2. Conduct of immigrant education, that prepares each individual for a life in diaspora, in civic participationalism.

3. Creation of an institutional order charged with immigration policy,

4. Realisation of a balanced development of immigrant life, combining diasporal values and traditions with the cultural challenge of the present and future,

5. Elaboration of tools and instruments to prevent the phenomena of immigrant life pathology.

Despite the categorisation of immigration as a civilisation phenomena and process a considerable diversity of reasons that generate it reveals itself.

The aspiration to ameliorate livelihood conditions is considered as the most typical motive for decisions about migration ${ }^{2}$. The generation of young people reveals great hopes for life stability, independence of action, civilisation advancement here (much better than in the case of their parents and family members). The generation of middle-aged people (over 30), who have their own families, searches to improve the livelihood conditions and orientates towards the creation of "equal chances" for their children. While young people (so called "singles", well-educated and, in addition to that, able to communicate in foreign languages at a satisfying level) usually achieve their basic immigrant life goals, the group of older persons experiences an "immigration failure"; they do not meet many basic existential needs, including finding employment at the level of individual and collective satisfaction. Their educational status is lower. The children are usually not able to accomplish tasks placed before them in the system of public schooling, therefore they steer towards gaining qualifications within the scope of certain branches of the service industry. Their educational status is lowered even in relation to their own parents, the level of participation in cultural life is lowered, which to a substantial

2 Ref. A. Chodubski, Kształtowanie się nowego oblicza instytucjonalnego migracji w Europie, [in:] Procesy migracyjne: teoria, ewolucja, współczesność, eds. L. Kacprzak, J. Knopek, Piła 2008, pp. 61-75. 
degree is connected with the linguistic barrier in social communication; participation in political life is minimised, it is usually limited to their own ethnic community.

Diasporal life is traditionally generated by such elements as: 1 . Institutional order, the functioning of various organisations, associations, unions, 2. Active leaders of minority life, open to both changes of culture and civilisation and to immigrant needs of their diasporal groups, 3. Churches and organisations of creed integrating the given communities in the religious, national-ethnic and social dimension, in the various regards of religious provenance, professional experience, interests, among these artistic, sports, entertainment; they constitute the most resistant strongholds of diasporal life, especially oriented towards nursing traditions, customs and more, 4 . Centres of education for children and adolescents and the functioning of the media, that show the most vital problems of immigrant and diasporal life, 5. Retaining of ties to the country of emigration and ones own diasporal communities.

These elements, still vital from the perspective of immigrant integration, undergo deep reorientations in a reality of civilisation changes ${ }^{3}$. And so, influenced by a fast pace of scientific and technological progress, including information technology, communication over great distance, shaping of international juristic order (including human rights), education oriented towards promotion of tolerance, acceptance of culture and civilisation syncretism, diversity of cultures, subcultures, the institutional reality changes dramatically. The dying out of traditional organisational structures is taking place. Paternalistic phenomena and processes are replaced by the participationalism of an individual. There is little interest in participation in formalised structures of social life among the youngest generation of immigrants and representatives of various groups of diasporal life. The traditional organisational structures gather mostly people of retirement age, which is connected above all with the need of integration for lonely people.

3 Ref. A. Chodubski, Wartości współczesnego życia kulturowego. Tożsamość Polaków w rzeczywistości diasporalnej, [in:] Wspólne drogi Polaków w kraju i na obczyźnie (19182008), eds. L. Kacprzak. M. Szczerbiński, Piła 2009, pp. 375-389. 
In the institutional reality the functioning of structures with rich values of socio-political and cultural activity, who are the actors of diasporal life in contacts with official factors of respective countries of settlement for immigrants, is retained. In some cases these are organisations existing since the $19^{\text {th }}$ or early $20^{\text {th }}$ century. Their activity can be observed above all in big diaspora communities. In a new migration reality organisational structures are often created for immediate realisation of given immigration tasks. They exist a few weeks or months. They assemble representatives of new immigrants, usually well-educated, open to the signs of civilisation changes in the world. A characteristic of new organisational structures is the departure from hierarchic rules of activity in favour of horizontal ties, embedded in the value order of liberty, equality and alternativity. New organisational structures usually orientate towards multiculturalism, which is expressed in linguistic communication. Yet organisational controversies reveal themselves here. Some of the members opt for universalisation of linguistic communication, i.e. for usage of the language of the country of settlement or the English language, although there are quite a few spokespersons for traditional linguistic communication, i.e. usage of the language of the given emigrant community.

The functioning of organisational structures depends to a substantial degree on the personality of their leaders ${ }^{4}$. The so called "old" diaspora remains in the circle of authentic leaders, committed to social life. These are above all people who have reached a satisfying level of livelihood in the immigrant life; they are often representatives of technical intellectuals, which manifests itself in the forms of activity organisation, with a high precision of realisation of the undertaken tasks. In the organisation of diasporal life they attach great importance to the nursing of tradition, including the celebration of national holidays, to observance of events from the political calendar, which is connected to religious rites. In the domain of socio-cultural life they prefer the amateur current to professional formulas of culture promotion. They reveal concern for the development of an amateur orchestra, singing, dancing, theatre groups and for

\footnotetext{
4 Ref. A. Chodubski, Rola elit w środowiskach polonijnych, [in:] Funkcje i zadania elit w środowiskach polonijnych, ed. J. Knopek, Toruń 2006, pp. 13-32.
} 
their presentation in accordance with the traditional calendar of the community's activity, i.e. most of all during the carnival season between Christmas and Easter and during autumn (October-November). Folk dominates the programme of these actors of artistic life (songs, chants, dance from various regions of Poland, often including Cracow, Silesia, Masovia, Łowicz, which are situated in the tradition on national level). In recent years referrals to compositions broadly promoted in the $60^{\text {s }}$ are observed, among others to the repertoires of Leszek Bogdanowicz, Mieczysław Fogg, Halina Frąckowiak, Anna Germann, Krzysztof Klenczon, Seweryn Krajewski, Krzysztof Krawczyk, Halina Kunicka, Janusz Laskowski, Wojciech Młynarski, Jerzy Połomski, Sława Przybylska, Irena Santor, Katarzyna Sobczyk, Piotr Szczepanik. These leaders are oriented towards the functioning of organisation in a semi-open order, i.e. above all realisation of challenges linked to nationality and ethnicity. Representatives of authorities governing in the places of activity and other activists of public life, including representatives of national minorities, are being invited to official celebrations. The leaders reach this acolyte usually in the process of activity within a given structure. Its achievement is a personal satisfaction and an obligation, a responsibility for decisions.

In new institutional structures organisers usually become leaders. These organisations are not big, they number from a few (6-9) to a dozen or a few dozens members. Among them are activists who realise specified tasks (usually oriented towards raising of funds with the goal of accomplishing given challenges) and people, families who support them. In the diasporal activity they concentrate most of all on promotion of the best domestic creations of culture. Before folk they place high professionalism, including talented musicians and their work, painting artists and their work acknowledged by the intellectual world of writers, journalists and figures of public life. These leaders are not rarely at the same time people from the world of culture and art; they often start their creative activity in the country of emigration. They have decided to emigrate in the hope of a better fulfilment of their passions, abilities, in hope of liberation from many so called autochthonous limitations. Emigration appears to people of culture and art usually as a reality of true freedom, justice, independence, as liberation from jealousy, envy, disinterested unkindness. Without 
a doubt, in the practice of their activity they have to "face" many barriers, not only of a professional, artistic nature, but also simple existential and livelihood challenges. The creation of structures in the institutional order is mostly a necessary challenge for them, a legalisation and promotion of their own activity. E.g. writers establish magazines with editorial offices, for it allows them to raise funds for publication of their own works, which also means promoting, inclusion in the so called circulation on the reading market. This reality constitutes a high conflict potential for creative milieus though, particularities of interest appear, so does intrigue, libel, contradictions of a different scale of influence ${ }^{5}$, all of which leads in consequence usually to brevity of functioning of newly established actors of the diaspora's cultural life.

This sphere reveals specific immigrant attitudes. Among them the following are characteristic: a) authoritarianism, b) fiction, c) isolation. "Emigration" appears to many people as no man's land. They find that it is possible to start living "anew" in immigrant life, not remembering one's own past, at the same time using the force of one's own authority, resoluteness, steadfastness, negation of authority and attitudes incompatible with one's own imagery. A high degree of intolerance, dogmatism and fear reveal themselves here.

Fiction is connected to the projection or roles played by many immigrants. They deform their own professional experience, revealing undervaluation at the same juncture. They announce that they possess e.g. experience in work as professional engineers, while in reality they were mere technicians, doctors - but actually nurses, journalists - officials in public institutions, actors - former soldiers, police force members, employees of the power apparatus.

They understand their period of emigration as social, professional degradation, regard themselves as "scapegoats", who are unjustifiably suffering responsibility for their one time co-workers. In immigration practice these are individuals who remain in a state of constant threat. Their

5 Ref. A. Chodubski, Radykalizm postaw ideowych oraz społeczno-politycznych diaspory polskiej, [in:] Piętnaście lat doświadczeń polskiej tranformacji, eds. W. Hładkiewicz, M. Szczerbiński, Zielona Góra 2004, pp. 163-180. 
"fiction" can be exposed by immigrants, and above all they reveal a high degree of incompetence within the realm of the sphere, they attempt to identify with. In this situation they reveal attitudes of aggression, defence of their fictitious social causes; often they socially draw near then to authoritarian individuals, who offer them a kind of moral support.

Isolation is a conscious distancing for one's own diasporal community; it is a path of solitaire functioning in immigrant reality. This reality leads to intellectual degrading though, to impoverishment of needs, to deformations within the scope of thinking and acting ${ }^{6}$.

Immigrant isolation frequently has an impact on the psychological health of the diaspora's people. Social life in a reality of constant incertitude, experimenting with roles generate stress, and in consequence apathy, indifference, psychological disorders. It is at the same time generally noticeable that decisions in favour of immigration life are made by people of high emotional sensitivity, prone to frustration and psychological illness.

In immigration life persons of a high degree of sensitivity reveal various defence mechanisms. Among these the following are of essence: a) identification - immigrants assigning themselves characteristics which they do not possess, $b$ ) projection - transferring of ones own negative characteristics onto other persons, c) rationalisation - explaining of ones own negative attitudes or social behaviour on a logical premises.

In the immigration order, media, especially written media, have much relevance. They are often the only source for obtaining information about the life of culture and civilisation for immigrants, both about the country (place) of settlement and country of emigration. Immigrants usually expect from them the most comprehensive information about phenomena and the processes of immigrant life, including the rights they are entitled to. The publishers of magazines, with the exception of local informational bulletins, try to report chosen political issues, shown from defined positions, ideological and political standpoints; usually they condemn both the unfavourable politics of global reality and certain tendencies generated in local realms. In this literature, tradition clearly clashes with the chal-

6 H. Olesiak, Polska emigracja polityczna w RFN. Szkice z psychologii społecznej, Düsseldorf 1987, pp. 71-73. 
lenges of the present. Publications, which have functioned for many years, orientate towards the so called inner confinement of immigration, the awakening of patriotic values, the recalling of classic culture achievements, e.g. the literary works of Adam Mickiewicz, Juliusz Słowacki, Henryk Sienkiewicz, the knowledge about Fryderyk Chopin, Maria SkłodowskaCurie, Ignacy Paderewski, etc. On the other hand, the young generation of immigrants opts for promotion of their own works. It attempts to establish new publications.

At the same time it tries to target a vaster circle of recipients, among others by printing in two or three language versions (Polish, English, the language of the given reality it is published in). This generation orientates towards pursuing access to television and radio, both in localities and on the national level for the given clusters of immigrants. They believe that the promoting of Polishness in programmes a few minutes long, in broadcasts, has a greater impact on social perception than a carefully elaborated amateur artistic movement (musical, choir performances), that is presented during various revues and festivals of the socio-cultural life.

A specific, debatable matter in immigrant life is the education of children and youth in the language of the country of emigration. On the one hand, a tendency to establish schools, especially so called Saturday-Sunday schools, where homeland education is passed on (in the fields of Polish language, history, geography, culture), reveals itself and generates bonds with the country of the "forefathers". On the other hand - it is noticeable, that this kind of education alienates children and youth from their new places of settlement, makes the adaptive and integrating processes more difficult.

In the immigration practice it is recognised, that individuals and families who experience adaptation barriers in the new cultural reality and anticipate re-emigration, opt for education in the language of the country of emigration. Saturday-Sunday schools are regarded as an oasis of Polishness, in which, beside the education of children and youth, their families meet and reveal commitment to organise the socio-cultural life (dance evenings, balls, excursions, pilgrimages, etc.). For this activity they frequently attempt to receive support from official factors representing the country of emigration (embassies, consulates, various actors of economical life). Individuals and families who successfully overcome adapta- 
tion barriers isolate from these forms of education and pedagogical activity. They attempt to isolate the children and youth from contacts with the cultural values of the country of emigration; the consequence of this is their rapidly progressing assimilation. It is observed that the third fourth generation of immigrants ceases to communicate in the language of the "forefathers".

In the reality of European changes, connected to the construction of the European Union and recognition of equality between member state languages, an interest in Polish language courses revealed itself. It is often chosen as a foreign language during studies by Poles.

A new reality in the diasporal order is observed with connection to the position of the Roman Catholic Church ${ }^{7}$. The church is for a majority of Poles in diaspora the most important "homeland" institution and both the representatives of the "old" and the "new" emigration participate in holy mass. They mostly arrive at churches, called Polish churches, during the most important holidays in the church calendar (Christmas, Easter, Corpus Christi).

In reality the functioning of personal parishes draws attention. They were established in $19^{\text {th }}$ and $20^{\text {th }}$ century in the rising clusters of Poles. On the trail of emigrants clergymen followed and organised the religious and socio-political life. In the process of cultural changes, including integration and part-assimilation, immigrants usually leave the "ghetto" life, they settle in dispersion. In doing this they also leave the churches and places of religious cult they have erected. Immigrants move to local churches, in the areas they inhabit. The strength of tradition is the reason why they frequently try to visit Polish churches, which they do especially on important church holidays and ceremonials such as wedding, baptism, first communion, and organisation of requiem mass. The integration of immigrants distances the people of diaspora from traditional order to a substantial degree.

The newest wave of emigrants, that settles is clusters, in certain districts of cities returns to traditional participation in religious life. E.g. in the United Kingdom the construction of Polish churches and a substantial level

7 Ref. Instruction Erga migrantem Caritas Christi, Lublin 2008. 
of participation in holy mass by the representatives of the younger emigrants can be observed. Priesthood plays an important role in the religious life of diaspora. By revealing commitment to religious, but also self-helping, socio-cultural integration of diaspora, priests gain the respect and recognition of immigrants. Immigrants from the so called "old" emigration address priests with different challenges though, different is the attitude of the young immigrants towards their functioning. Representatives of the "old" immigrants expect the priests to nurse tradition, rites, to commit to sociopolitical causes. From the life of the parish they expect the creation of a "substitute for the country of emigration", and at the same time not rarely the fulfilment of regional values, e.g. of the Podhale region, Silesia, Podlasie. On the other hand, the young generation of immigrants expects the priests to play the role of leaders, universal guides in the world of changing values. High expectations are placed before them within the scope of the organisation of socio-political life, intellectual activity, understanding of the world of culture and art. Priests are expected to know legal solutions and the cultural characteristics of certain places (clusters of Polish diaspora), to be open to the signs of scientific and technical progress, to forms of recreation and rest. Broadly speaking, priests are expected to have a deeply humanistic attitude, embedded both in the universalism of civilisation and in the diversification order of the given cultural spaces.

In general, contemporary priests, who work in the Polish diasporal value, satisfy the religious needs of the faithful. Substantial differences reveal themselves though, resulting from the level of development of culture and civilisation in the countries where Polish diaspora functions, from its size, level of commitment, attachment to religious values. Another role is played by missionaries, who offer priesthood services, and priests who work in personal parishes and have a traditionally consolidated position in given countries and among Polish diaspora. Yet in a situation of low participation of the faithful in the life of a personal parish the upkeep of churches and parish life by priests is not possible. An exemplification of such reality is constituted by New York City, where the transferring to other actors of public life is taking place ${ }^{8}$.

8 D. Piątkowska, Polskie kościoły w Nowym Jorku, New York-Opole 2002; ibidem, 
The picture of diasporal life is altered by the signs of changes, which are called global. Among them the following can be observed: 1 . Conversion of ethnic communities bound by emotional signs into a reality of interest groups connected by the sphere of marketing, 2. Departure from behaviour, attitudes of a ethical, moral value in favour of effective action, 3. Replacement of traditional family life, neighbourhood values, professional relations with the signs of commerce, exerted gains, especially material ones, 4. Replacement of traditional communities (family, neighbour contacts) with prestige, commercial relations (banquets, recreational excursions), 5. Obliteration of boundaries between truth (about one's self, family) and stage-set, spectacle (identification, projection of certain values), 6. Obliteration of boundaries between work and unemployment, between legal and illegal activity, between work and rest, 7 . Technicalisation of social life that generates dehumanisation, infantilisation, barbarisation of cultural relations, mostly sensed in social relations, 8 . Obliteration of boundaries between the transmission of true information about a given reality and disinformation and manipulation, which can be observed especially in the domain of political life, 9. Ousting of competence, of reality valuation, including the occurring changes, by the media presence. The media, by their calling - the fast supply of information, they oust intellectual reflection, credibility in recognition of a given reality, 10 . Ousting of democratic ideals by authoritarian and plutocratic order in the decision processes.

These values encourage the attitudes, the behaviour of immigrants to join the unification processes. In the face of the simultaneous revealing of globalisation and diversification processes, including the nursing of signs of distinctive national and ethnic identity. It is recognised that this is a declarative sphere, the expression of difficulties to adapt to the revealing of new civilisation challenges. While declaring acceptance for the development of (ethnic) minority life, its clear confinement can be observed. The identification with the values of tradition is considered as a sign of conservatism, "backwardness" of civilisation.

Getta czy otwarte społeczności etniczne?, [in:] Polonijny Nowy Jork, ed. D. Piątkowska, New York-Opole 2010, pp. 139-156. 
The fast pace of civilisation changes clearly generates divisions within diasporal communities in: a) "old" and b) "new", "modern". This division is dictated most of all by the immigrants' attitude towards the progress of science and technology and the introduction of its results into daily life. The generation of immigrants, with biographies longer than 50 years, usually reveals a detachment from the signs of modernity, here including information technology equipment; it attaches great importance to the usage of this kind of equipment as long as possible, which "excludes" it from the domain of modernity.

On the other hand, the "new" immigration orientates towards such signs as: 1 . Temporariness (short-term) of functioning, 2. Changeability of attitudes, behaviour, values, including the sphere of social contacts, 3 . Prioritizing of signs of material life and living standards over the spiritual, intellectual order, 4. High level of tolerance with regard to diversity of culture signs, 5. Individualism (in the sphere of social life, including family life), 6. Orientation towards the mastering of signs of scientific and technological progress, among others in the sphere of information, communication technology usage, 7. Acceptance of cultural syncretism as a value of culture and civilisation (perception of the world as a "diversity co-creating unity"), 8. Prioritizing of legal solutions over ethical and moral obligations, 9. Rejection of signs of tradition, of responsibility in favour of risk and the playing of new social roles, 10 . Strive towards anonymity of life, limitation of contacts with family, neighbours.

These signs generate the so called postpostpostmodernism of individual, which is contained in: a) instant consumerism in the sphere of economic life, b) changeability of options, attitudes, values in the sphere of socio-political life, c) technicalisation of cultural life; satisfying of traditional needs in culture and art with technical equipment.

Trailing this model, a high legibility is obtained by tendencies to replace cultural tradition with the signs of the "spirit of times", i.e. a) truth by the political correctness of given times, b) authorities - by idols, c) real evaluations of surrounding reality - by measures of public opinion, especially obtained by means of polls, d) solidarity - by utilitarian individualism, e) ethical, moral rules - by effectiveness, achievement of set goals. 
The "newest" immigration generates new tendencies in the construction of relations between diasporal life and the country of emigration (native land). Its dislike of governing authorities is lowered. To a lesser degree they are accused of inability to govern the country, at the same time of generating emigration ("pushing" own citizens out into "diasporal exile"). They exhibit interest in political life in the country of settlement, which is expressed among others by participation in elections of the highest representatives of power. This attitude is generated to a substantial degree by the media, geared towards bringing the processes of global changes into consciousness, including the acceptance of migration as a value in the contemporary life of cultures and civilisations.

Newest immigrants often do not regard their stay and work outside Poland as emigration, but rather as reality, a regularity in the process of global changes, as a challenge of freedom, a value of cultural syncretism, as a right to an independent decision about the place of settlement and as the assumption of the option for self-realisation. Space, distance between the place of emigration and the new settlement is not regarded in its traditional understanding. This is obliterated be the modern forms of travel, especially air travel. The notion of "livelihood belongings" undergoes a re-valuation. Newest immigrants do not attach great importance to it. They purchase the indispensable objects, which they use for a certain period of time, in case of change of location and settlement in new places they purchase new objects. The so called permanent objects of migration are often constituted by personal IDs only. Marketing order reveals itself at this point. The consideration of achieving higher income causes the immigrants not to attach significance to spatial identity. The phenomena of life "in a swing" reveals itself here, people leave for work for a certain period of time, often without legalisation. In the extraeconomical dimension migrations with educational goals are characteristic - with the intention to master a given language, obtain professional qualifications.

By analysing migration in the category of "gains and losses", that reveals itself both in emigration countries and those receiving immigrants, many important phenomena are observed, especially in the context of further 
development strategy ${ }^{9}$. And so, among the losses for the country of emigration the following can be mentioned: a) weakening of demographic potential, including within the scope of birth-rate, caused by the outflow of young people, b) distortion of age structure; "acceleration" of population ageing, especially in smaller structures of people, in the face of the abandonment by young people, and, trailing this, the revealing of deformations in functioning of social infrastructure (schools, institutions, health care, sports and recreation), c) changes in the image of family life; creation of incomplete models of family life, d) intensification of social pathology phenomena, due to the increased dysfunctionality of hitherto existing institutions of socio-economical life, e) economical degradation of desolating areas.

Countries receiving immigrants bear the costs connected with the necessity to create basic infrastructure for them and to guarantee security in the face of pathologies revealed in the process of adapting and integrating immigrants (among others resulting from the feeling of so called exclusion, post-colonial discrimination).

Among the gains for countries receiving immigrants are the following most commonly mentioned: a) strengthening of the labour market by an influx of a young work force, b) recruitment of people with substantial intellectual potential (well-educated people, specialists with a university degree - doctors, pharmacologists, engineers, scholars), c) creation of a new civilisation order - multiculturalism, multiethnicity.

On the other hand, the country of emigration reduces the extent of unemployment, due to spatial mobility of immigrants it obtains investment capital, amelioration of quality of life in immigrants' families, mobility of the young generation, which achieves new professional abilities, cultural values, in the reality of diasporal life.

In general the vision of Polish immigrants, despite a high level of openness towards the signs of civilisation change, reveal a strong attachment to the value of family tradition, to the Place they originate from (its magic),

9 Ref. Polacy wśród Europejczyków, eds. A. Jasińska-Kania, M. Marody, Warszawa 2002; Z. Kawczyńska-Butrym, Migracje. Wybrane zagadnienia, Lublin 2009. 
to cultural values passed on from generation to generation, which guarantee a sense of security, and consciousness of one's own place in the surrounding world. They regard diasporal life as a specific kind of "orphanhood", as functioning in a "foreign" international environment.

In the diasporal order values of personality and enrichment are accepted, thanks to the functioning in multiculturalism, especially in the process of education, and professional work; it is recognised that immigration is always an illegal reality.

Within it, signs of tradition and modernity, incertitude, extemporaneousness, superficiality of attitudes, behaviour of individuals and social groups clash with each other.

In generalising afterthought the following can be stated:

1. In the reality of shaping an information civilisation order a new "quality" of society (citizenship) is generated, and within it new cultural practices, that open possibilities and cause threats for immigrants, reveal themselves,

2. In the formation of new immigrant reality important challenges are aimed at education, called migration, in which both emigration and immigration phenomena and processes require recognition and conscious realisation,

3. Currently the media became the major subject generating attitudes of societies towards migration and immigrants and they show the phenomena and processes in a superficial manner, frequently in a sensational and descriptive manner. This interpretation is also grounds for the institutions of public life to formulate evaluations on migration,

4. The Poles in diasporal reality, despite a not rarely revealed openness towards the signs of civilisation changes, constitute a community strongly attached to family, educational, confessional tradition, and also locality (so called magic of sacrum loci),

5. In the formation of diasporal life of the Poles the Roman Catholic Church plays a remarkable role. Culturally vital is its mission in adaptation and the integration processes, also in the reality of deep civilisation changes (shaping of information civilisation), where it 
stands guard for combining tradition with the challenges of the present and future.

The description of migration phenomenon as "no man's land" generates important threats to humanity today, which is connected with the obliteration of boundaries between responsibility and irresponsibility, truth and falsehood, ethical and unethical. 